\title{
Attempts at romanizing the Hebrew Script and their failure: Nationalism, religion and alphabet reform in the Yishuv
}

Illker Aytürk

To cite this article: Ilker Aytürk (2007) Attempts at romanizing the Hebrew Script and their failure: Nationalism, religion and alphabet reform in the Yishuv, Middle Eastern Studies, 43:4, 625-645, DOI: $10.1080 / 00263200701348920$

To link to this article: https://doi.org/10.1080/00263200701348920

Published online: 12 Jun 2007.

Submit your article to this journal $\sqsubset$

Џلll Article views: 208

Citing articles: 2 View citing articles ๘ 


\title{
Attempts at Romanizing the Hebrew Script and their Failure: Nationalism, Religion and Alphabet Reform in the Yishuv
}

\author{
İLKER AYTÜRK
}

While describing the difficulties he experienced in Mandatory Palestine, Arthur Koestler called attention to his struggle with the Hebrew alphabet and complained thus: 'I have spent on and off altogether some four years in Palestine and speak Hebrew fairly fluently, but am still incapable of reading a newspaper, to say nothing of books. The majority of new immigrants are in the same position. ${ }^{1}$ For Koestler, the Hebrew alphabet not only made life difficult for new immigrants, but it also cut off the ties that allied Jews with western culture. Therefore, he proposed a solution:

The only way to avoid the dangers of cultural isolation and stagnation seems to be the latinization of the obsolete and cumbersome alphabet. If this revolutionary measure could be carried out in backward Turkey, one would have expected it to meet with little resistance in this predominantly European community. ${ }^{2}$

Koestler's proposal in the late 1940s was not original; arguments in favour of romanization could be seen as early as the 1920s and were upheld by a small circle of intellectuals in the Yishuv - a term which describes the Jewish population and settlement in Palestine before the establishment of the State of Israel. Its first and foremost advocate had been Itamar Ben-Avi, who worked harder than any other person to popularize the romanization of the Hebrew script; the idea struck roots also among the Revisionist Zionist intellectuals under the influence of the founder of the movement, Vladimir Zeev Jabotinsky. This article aims at reconstructing the social, political and intellectual climate in which such romanization attempts were made, describing the unfolding of those attempts and, finally, explaining the causes of failure.

Conservatism that favours an established system of script and spelling is a widespread phenomenon and is understandable from the point of view of a speech community, since letters, logograms and pictograms are not just the media of conveying culture and knowledge. According to Jack Goody, an anthropologist who distinguished between oral and literate modes of communication in a number of 
path-breaking studies, alphabet, and script in general, has been of great importance in human history in that it made intra- and inter-generational communication possible. ${ }^{3}$ The invention of writing had been a revolutionary event because of the fact that communication between contemporaries and between generations could now be made without human intermediaries for the first time. Implications of this revolution were enormous: not only did writing help preserve data in its original form - in contradistinction to oral cultures that blend facts with myths - it also paved the way for the accumulation of knowledge.

The association between writing systems and religions/civilizations is another striking phenomenon. Roman characters had, since the early medieval period, been identified with the Roman Empire and, then, with the Roman Catholic Church. From its Roman origins, this script first reached Western and Central Europe, and the sixteenth century witnessed its overseas expansion to the Americas and other European colonies. Until the twentieth century, the Roman alphabet had never been adopted outside the boundaries of western Christendom, as other civilizations employed their own alphabets. A fault line separated the Roman alphabet, on the one hand, from non-Catholic Christians, who continued to use the Cyrillic, Greek, Coptic, Amharic and other alphabets, and, on the other hand, from the Muslims for whom the Arabic alphabet was a common medium. ${ }^{4}$ Therefore, the Roman alphabet was the alphabet of the 'other' for the non-Catholic Christians as well as the Muslims, Jews and other Asian peoples. In other words, the borders of alphabets neatly overlapped with the borders of civilizations. Generally speaking, alphabets or scripts of holy texts assumed significance beyond their utility in this context. As Florian Coulmas aptly put it, '[o]nce written norms are established, they attract emotional attachment'; so strong an attachment indeed that 'discussions about the reform of a given orthography or script often resemble a religious war more than a rational discourse, generating more heat than light'. ${ }^{5}$ This may explain why changes of script happen only very rarely. ${ }^{6}$ The textbook example of a successful case in the twentieth century is the romanization of the Turkish script in 1928. Similar changes were effected by the Turkic peoples of the Soviet Union during the 1920s, shifting from the Arabic to the Roman, then to the Cyrillic alphabets. Likewise, the Hausa of West Africa introduced the Roman alphabet in place of the Arabic under the influence of Christian missionaries. All these successful cases of script change were preceded and accompanied by deep social transformation, religious conversion or secularization of the speech communities. However, full-scale transformation of a given society, religious or otherwise, does not alone guarantee the success of script change, as illustrated by the Chinese case. Although the People's Congress in revolutionary China adopted a phonetic alphabet in 1958, the so-called Pinyin, to replace the Hanzi writing system, the change did not become popular. In this respect, each attempt at changing script has to be studied in its own right, taking into consideration a number of factors that facilitate change or inhibit it. ${ }^{7}$

In order to understand the gravity of a proposal such as the romanization of the Hebrew script, which was possibly first heard of at the end of the nineteenth century, and to appreciate the magnitude of the change that that proposal entailed, it is necessary to take into account the religious and emotional attachment to the traditional Jewish alphabet. The present Hebrew alphabet, which is commonly referred to as the Aramaic, Assyrian or simply the square alphabet, was actually not 
the first Jewish alphabet. The original Hebrew alphabet was descended from the Phoenician branch of the ancient proto-Canaanite script and dated back to the ninth century BC approximately. ${ }^{8}$ It remained in use well into the Second Temple period, until it was gradually eclipsed by the ancestor of the present, square script from the fourth to the second centuries BC. According to the Talmud, the square letters were first introduced by Ezra when he returned from the Babylonian exile, ${ }^{9}$ while modern researchers trace their origin to the large scale linguistic transformation in Palestine, whereby Aramaic, the diplomatic language of the Near East at the time, replaced Hebrew as the colloquial language of the Jewish elite and the masses. Since then the square letters have enjoyed unparalleled authority and prestige among the Jews. It is true that there were cases when Jewish communities in the Diaspora started to employ other alphabets - the Arabic alphabet, for instance, in the case of the Jews of Spain and Arab lands in the medieval period - though such usage was generally limited to daily life and scholarly purposes. The predominance of the square alphabet remained uncontested, especially in the religious literature.

The reverence for the square script was ingrained in the Talmud and Jewish lore. It was Bezalel's talent in combining the letters of the alphabet that led to the successful construction of the Tabernacle. ${ }^{10}$ The same letters had an indestructible quality. When Moses broke the Tablets of the Decalogue, the letters simply flew upward to heaven. ${ }^{11}$ In the same way, they 'soared on high' when the Roman soldiers wrapped up Rabbi Hananiah ben Teradyon in a Torah scroll and burnt him alive. ${ }^{12}$ Ahab, the sinful king of Israel, was granted 22 years of rule on account of his refusal to surrender the Torah to the king of Aram, for the Torah was composed of 22 letters. ${ }^{13}$ The letters were also believed to have played an important role in the creation of this world:

When God was about to create the world by His Word, the twenty-two letters of the alphabet descended from the terrible and august crown of God whereon they were engraved with a pen of flaming fire. They stood round about God, and one after the other spake and entreated, 'Create the world through me!' ${ }^{14}$

Similarly, the letters of the Hebrew alphabet had taken on a significance in Jewish mysticism, where the kabbalistic tradition attributed secret meanings to every letter. Each was assumed to represent a spiritual essence, an emanation from God; and their particular combinations, therefore, were expected to bring about changes in the cosmos and alter the course of life. ${ }^{15}$ That is why the exact wording and spelling of ritual formulas, prayers, incantations and documents such as the Torah, the tefillin or mezuzot are regarded as of critical importance, since a misspelling might easily upset the delicate balance of forces that govern the spiritual and material well-being of the owner. In addition, the letters of the Hebrew alphabet served as numerical signs since there is no separate Hebrew numeral system. This gave birth to gematria, a tradition of associating words, whose numerical value are the same, to reveal information about the future and the coming of the messiah. All in all, the square script had indeed come to play an important role in the daily life of the Jewish people.

The reform of the Hebrew alphabet has been an issue that engaged many linguists and interested individuals who were not experts themselves. There is, however, an 
overall agreement that the present Hebrew alphabet creates difficulties in reading a Hebrew text and that it poses a challenge to anyone who studies the language, and sometimes even to the native Hebrew speaker. The difficulty of the pointing system, the relative lack of vowel signs, the graphic resemblance of the letters 7 and $\urcorner, ב$ and $J, \pi$ and $\pi, \cdot$ and $r, 0$ and $[$, are among the problems that led many to devise orthographic and graphic reform projects for the Hebrew alphabet. ${ }^{16}$ Romanization is only one of those proposed reforms and entails the substitution of a modified version of Roman characters for the traditional, square letters of the Hebrew language.

The most important figure in the brief history of the romanization of the Hebrew language both in the Diaspora ${ }^{17}$ and in the Yishuv was Itamar Ben-Avi (18821943). ${ }^{18} \mathrm{He}$ was born in Jerusalem as the first child of Devorah and Eliezer BenYehuda, who had recently settled in Ottoman Palestine in order to establish there a community of Hebrew speakers. Itamar suffered as a result of that experiment, when his father confined him within the walls of the family home so that he would hear nothing but Hebrew. He was able to utter his first words much later than other children of his age. But he was indeed the first Jew to speak Hebrew as a mother tongue in centuries and was, therefore, considered a miracle, an extraordinary specimen of the 'New Jew'. ${ }^{19}$ As a matter of fact, Ben-Avi's experience marked his attitude toward Hebrew during the rest of his life. That he spoke Hebrew as his first language set him apart from his contemporaries, who studied Hebrew later on in their lives and came to revere it as a holy tongue or as the depository of Jewish culture. Ben-Avi never adopted such a reverential attitude. On the contrary, he is known to have referred to Hebrew as his pilegesh (Hebrew for concubine), a plaything to be fixed at will. ${ }^{20}$

He first went to Paris to study at the Teachers' Seminary of the Alliance Israélite Universelle and also participated in seminars at the Oriental Studies Department at the University of Berlin. He returned to Jerusalem in 1908 and assisted his father in his journalistic work. Soon he made a name for himself as a fine author, editor and journalist. He was the editor of such important newspapers as Do'ar ha-yom and Palestine Weekly, and served as the Jerusalem correspondent of several British and French newspapers. He put his oratorical skills in many languages into use when he agreed to work for the Jewish National Fund. He was in the United States for a lecture tour when the Second World War broke out. He died there in 1943 and his remains were laid to rest in Jerusalem in 1947.

In several of his publications, Itamar Ben-Avi claimed that he was inspired in his quest for the romanization of Hebrew script by his celebrated father, Eliezer Ben-Yehuda. According to Ben-Avi, in the 1880s his father wanted to print his very first newspaper in Jerusalem, Mevaseret tziyon, in 'what is, by mistake, called until today the Phoenician alphabet'. ${ }^{21}$ It was Devorah, the first wife of Ben-Yehuda, who talked him out of this idea by arguing that such a move would make it difficult to read the Hebrew language and restrict the number of possible readers. Nevertheless, the project of romanizing the Hebrew language was so dear to Ben-Yehuda, according to Ben-Avi, that he realized his aspiration in his great Hebrew dictionary by publishing those ancient letters at the beginning of every new letter. According to this view, Ben-Yehuda might also have been discouraged by the reaction of the members of the Old Yishuv, who were extremely hostile to him. ${ }^{22}$ In the famous 
biography Ben-Avi wrote about his father, he reported a dialogue between BenYehuda and himself, which took place when he was only a small child:

- Tell me, please, how did it happen that you, a revolutionary man and a man of steel, did not also find the way to impose the Latin script on the Jews? And my father answered, saying:

- You are right, my son, but I did not want to damage two things - the word and the script [ba-mîlah ûva-ketâv].

- And what do you say if I, myself, dare do what you have not? And my father tussled tufts of my hair with his thin fingers:

- Be daring as much as you can, my son, because success lies only in daring. ${ }^{23}$

It must, however, be stated that Eliezer Ben-Yehuda did not commit himself to the idea of romanization in print and that there are no testimonies other than Itamar Ben-Avi's to that effect. Hemda Ben-Yehuda, Eliezer Ben-Yehuda's second wife, related an interesting conversation that further complicates the story:

Once during a conversation, between Ben-Yehuda, Ben-Avi and Jabotinsky, the latter reprimanded Ben-Yehuda for not changing the present Assyrian Hebrew alphabet [the square letters] for Latin characters. 'If you had done it, it would have now been a fait accompli.' Ben-Yehuda answered, smiling, 'After my death.' Until now, it is not clear whether Ben-Yehuda objected to it, or that he thought that the time was not ripe for it. ${ }^{24}$

It is, then, reasonable to assume that, although Eliezer Ben-Yehuda's position on this matter was far from clear, Itamar Ben-Avi made an effort to recruit his father's name for his romanization project.

According to his own account, Itamar Ben-Avi started to toy with the idea of romanization while he was still a high school student. At the Alliance school in Jerusalem, where he studied in the mid-1890s, Ben-Avi taught Hebrew to his classmates, Muslims and Christians, in the romanized script. The experiment was very successful and it dawned upon him for the first time that this might be the way to break the barriers between the Jews and Gentiles by teaching the latter the Holy Tongue without the difficulties involved in learning the square script. ${ }^{25}$ He followed the same method at the Alliance Seminary in Paris in 1899 and then at the University of Berlin, where two of his students were Judah Leib Magnes and Arthur Biram, the future founding rector of the Hebrew University of Jerusalem and the future principal of Ha-reali School in Haifa, respectively. ${ }^{26}$ According to Ben-Avi's memoirs, the future chairman of the World Zionist Organization, Otto Warburg, decided to sponsor his romanization project and offered a contribution of 1,000 German marks toward the preparation and publication of a Hebrew dictionary in Latin characters. Ben-Avi approached the famous publisher of dictionaries, Langenscheidt Verlag, which was also publishing his father's magnum opus. The publisher referred the question to Professor Eugen Mittwoch of the University of Berlin, who nipped the idea in the bud by calling the project 'ridiculous, nonsensical, offensive and treasonous', and by casting doubt on the academic credentials of Ben-Avi. ${ }^{27}$ In 1901, he met a young teacher at Rishon Le-Tziyon by the name of 
Mamman, with whom he prepared a Hebrew-Latin alphabet that could be applicable to Arabic as well. They corresponded several times using their new script. ${ }^{28}$

After completing his studies in Berlin, he returned to Jerusalem in 1908 and at around the same time Itamar Ben-Avi asked his father, Eliezer Ben-Yehuda, to spare one page in his newspaper, $\mathrm{Ha}^{-}$'or, for articles in Roman letters. He received a negative answer, though Ben-Yehuda said that he would not oppose a special weekly in that alphabet if Ben-Avi really believed in its usefulness. ${ }^{29}$ Upon his father's recommendation, Itamar Ben-Avi planned publication of a new monthly journal, Kidron, in 1913. He even gathered the material that would appear in the first issue of the journal, including a poem by Dr. Ariel Ben Zion of Jerusalem, all rendered in the Roman alphabet. But at the last minute, a 'well-known Jerusalem rabbi' - Ben-Avi did not mention his name - contacted him and requested that he prevent a scandal in the holy city. It is not exactly clear why, but the request was granted and that was the end of the Kidron project. ${ }^{30}$ Nevertheless, Ben-Avi did not shelve his plans in spite of these temporary setbacks. From 1913 to his escape from Palestine during the First World War, Ben-Avi prepared his book of poems and novelettes, entitled Berakim, in the Roman type, which he hoped to publish eventually in Jerusalem. The book was ready for publication when the Ottoman military governor of Jaffa, a Hassan Bey, confiscated all his notes and papers. ${ }^{31}$ The Ben-Yehuda family was in exile in the United States from 1915 onwards and Ben-Avi arranged evening classes for the American Jews where he taught Hebrew with the help of his romanized script. The exceptional progress of the students proved, according to him, the practicality of the Roman alphabet in teaching Hebrew especially to an audience that is not familiar with traditional Jewish culture and learning. ${ }^{32}$ With the British conquest of Palestine in 1918, Itamar Ben-Avi returned to Jerusalem with his family and soon became a very, if not the most, influential journalist and editor in Mandatory Palestine.

It seems that, at this point in his life, Itamar Ben-Avi adopted a new ideology under the influence of the nationalist circles that he joined in Jerusalem and Tel Aviv. $\mathrm{He}$ became one of the precursors of the Canaanite movement in Palestine, which was to nourish a flamboyant philosophy of nationalism later on in the 1940s and 1950s, one that transcended the boundaries of Zionism and Jewish nationalism, and espoused the unity of the peoples of the Levant. ${ }^{33}$ Ben-Avi, however, did not subscribe to the views of the extremist Canaanites. He always considered the Jews as the constitutive and most important element of the Canaanite nation and sometimes even gave the impression that his advocacy of the Canaanite ideology was in fact a means to legitimize the presence of the Jews in what was considered the Arab lands in the Middle East. ${ }^{34}$ Whatever the case may be, the alphabet question remained a staple of Ben-Avi's Canaanism. Starting from 1920s, he asserted that the concept of a 'Roman' or 'Phoenician' alphabet was a misnomer and that the proper name for this alphabet ought to be the 'Hebrew' alphabet. Historians of the alphabet, as distinct from pictographic and logographic writing systems, agree that the Romans derived their alphabet from the Greeks, who in turn borrowed theirs from the Phoenician alphabet. Ben-Avi, however, argued that the alphabet was not originally a Phoenician invention. The alphabetic writing system, he said, was revealed to Moses on the Mount Sinai, when he was presented with the Tablets of the Decalogue. This became the national writing system of the Israelites and, according 
to Ben-Avi, it was the tribe of Zebulun, who inhabited the western Jezreel Valley, that taught the Phoenicians the benefits of the alphabet over the pictograms. He wanted to announce to the world that what is called the Roman alphabet 'is nothing but the slightly modern version of the ancient Hebrew script'. ${ }^{35}$ Therefore, he hastened to correct a misunderstanding: 'Here is the truth - the aim of the author of these words [Itamar Ben-Avi] was not to romanize the Hebrew script, but to hebraicize the Roman alphabet'. ${ }^{36}$ Of course, Ben-Avi meant to provide a religious legitimacy to his scheme and wanted to pull the rug from under the feet of those who accused him of attacking traditional Jewish values and institutions. He took the ancient Hebrew letters very seriously, so much so that the logo of the family publication house (Ben-Yehuda hotza'ah le-'or) depicted the map of Palestine, including both banks of the Jordan River, with a Hebrew motto in that script. In a similar fashion, the iron fence that surrounds the grave of his father, Eliezer BenYehuda, in a Jerusalem cemetery bears an epitaph in Hebrew, written with the same ancient letters. ${ }^{37}$

The publication of $A v i$ (My Father) in 1927, a Hebrew biography of Eliezer BenYehuda in Latin alphabet, marked the beginning of Ben-Avi's struggle for romanization, not only in the family or private circles, but also in public. ${ }^{38}$ Preparation of the book occupied him for several years and then he had to find a publication house that was willing to publish such a controversial book and one that also owned the characters required for the transliteration. When the book finally came out, it created quite a stir in the Yishuv. There were only a few supporters ${ }^{39}$ and, although Ben-Avi praised the 'immense' response in the Yishuv and in the Diaspora ${ }^{40}$ for many the publication of the biography amounted to nothing less than a scandal. $A v i$ was not taken as a biography of a father written by his son: the majority of the readers saw in it the betrayal of the legacy of the father by his son, ${ }^{41}$ the end of the dream of Eliezer Ben-Yehuda, and a final step toward the assimilation of the Jews.

Itamar Ben-Avi's second attempt at realizing his life's dream came in late 1928, to be more precise, on 14 December 1928. On that day The Palestine Weekly, an English daily newspaper edited by Ben-Avi, started to publish a weekly supplement in Hebrew, using Roman characters, Ha-shavu'a ha-palestini. ${ }^{42}$ The subtitle of the supplement was in English: 'Hebrew Sheet in Latin Characters (For the Benefit of Gentiles and Jews Not Conversant with the Square Script)'. As suggested by the subtitle, one of the principal aims of Itamar Ben-Avi in publishing this most unusual newspaper was the propagation of Hebrew as one of the three official languages of Mandatory Palestine. In his eyes, Ha-shavu'a ha-palestini was:

the first Hebrew newspaper in the world in Latin letters, that is, in principle, intended for the Muslims and Christians who want to study our beautiful language. But also, those Jews, who do not know [how] to read Hebrew in square (Assyrian) letters - will indeed find in this newspaper a good opportunity to study the language of the Tanakh in less time.... We are certain that our male and female readers will appreciate this effort of ours to spread our language in the Jewish Diaspora and in the Christian and Muslim worlds. ${ }^{43}$ 
He also wanted to create a Jewish Esperanto, not a new language, but rather an Esperanto in the form of a common and accessible alphabet, for the benefit of the Jews all over the world. In this way, millions of Jews, who were discouraged, he thought, by the daunting square letters under the present circumstances, could speak Hebrew with one another. ${ }^{44}$

However, the subtitle probably revealed only part of the story behind the publication. One can argue that there were two more reasons that possibly motivated Ben-Avi in undertaking this and future projects of romanization. First, starting in the late 1920s Itamar Ben-Avi emerged as the foremost proponent of the cantonization plan for ending the nationalist struggle that plagued the Mandate government from its very beginning. According to the cantonization plan, which was presented as an alternative to various plans of partition, Palestine was to be politically divided into two self-governing cantons, resembling the Swiss model. The areas that were purchased and settled by the Jews would constitute the Jewish canton and the Arab canton would comprise the rest of the Mandate territory. Each canton was supposed to be autonomous in its internal affairs, while a federal government that consisted of the representatives of the two cantons would have control over foreign affairs and defence. ${ }^{45}$ Reminiscent of the optimism that pervaded Herzl's Altneuland, Ben-Avi continued to support cantonization, which was premised on the brotherhood of and future good relations between the Arabs and the Jews, despite the open hostility of the mainstream Zionist, as well as the Arab, leadership toward this plan. ${ }^{46}$ Romanizing the Hebrew and Arabic scripts was a central tenet of Ben-Avi's strategy to create a common polity for the Palestinian Arabs and the Jews, similar to what he had suggested to Mustafa Kemal for the Ottoman Empire almost two decades before. ${ }^{47}$ Ben-Avi urged fellow Arab intellectuals to introduce Roman letters into Arabic. He maintained that 'such a reform in the arabic [sic] languages, too, would be of a great benefit to this sister language of the Hebrew. That such a reform is featsible [sic] is best shown by the example which Tuhkey [sic] is settling now'. ${ }^{48}$

In April 1929 Ben-Avi took an even more daring step and announced that 'a special page of news in Arabic in Roman characters will be given in the supplement so that those not conversant with the Arab script may easily learn the other official language of Palestine, our common country'. ${ }^{49}$ In the same issue, the first and last such collection of Arabic news items was published in romanized script. ${ }^{50}$ In May, we learn that 'the Arabic press of the country has risen in vigorous protest against such an innovation', for it presents 'an absolute danger to the future of the Arabic language in Palestine'. ${ }^{51}$ A Jaffa paper, Falestin, predicted a quick end to the Arabic supplement, whereas the editor of Iqdam looked for an 'ulterior motive, political or otherwise'. As the outrage grew into proportions that he did not foresee, Itamar Ben-Avi was hardpressed to defend his endeavour. He mentioned his devotion to Palestine as a common country for both peoples, which, however, had yet to construct a patriotism of its own. This could be achieved through spreading the knowledge of the two main languages of Palestine, Arabic and Hebrew, and romanization seemed to Ben-Avi one of the means to create Palestinian patriotism and thereby facilitate a smooth transition to a State of Palestine, composed of two cantons. ${ }^{52}$

Second, Itamar Ben-Avi might also have been motivated to romanize the Hebrew script by what one may call his westernizing instinct. During his lifetime Ben-Avi had the reputation of a westernizer, who wanted to refashion the Jewish community in 
Mandatory Palestine as a western nation. ${ }^{53} \mathrm{He}$ was a great admirer of strong leaders like Mustafa Kemal Atatürk and Benito Mussolini, who, in Ben-Avi's eyes, made it their lives' mission to modernize and transform their countries. What Ben-Avi meant by modernization and westernization was the eradication of the visible differences that distinguished Jews of the Yishuv from the citizens of a Western European country, apart from those details that bound Jews as members of the same nation.

It is a difficult task to evaluate the success and political clout of Ha-shavu'a hapalestini in the Yishuv of the late 1920s. Ben-Avi himself claimed that it was more successful than he expected. He mentioned the high demand for his newspaper in Tel Aviv, where every issue sold out and many kiosks demanded an additional supply of copies. ${ }^{54} \mathrm{He}$ was hopeful regarding the number of subscribers, which alone could guarantee the publication of Ha-shavu'a ha-palestini on a permanent basis. Ben-Avi prided himself on new subscribers from all over the world as far away as Bombay and New York ${ }^{55}$ and was particularly satisfied when news had reached him that his newspaper occupied a significant place in an exhibition at the New York Public Library. ${ }^{56}$ Despite his optimism, we know that the number of copies actually sold was lower than Ben-Avi's expectations. The first two issues were distributed gratis to the subscribers of The Palestine Weekly. The third issue sold 25 copies, the fourth 40, the fifth close to 100 . Following the sixth issue sales peaked at around 150 copies in Tel Aviv, another 150 in the rest of the Yishuv, in addition to 44 overseas subscriptions. ${ }^{57}$ All things considered, Itamar Ben-Avi could not have created momentum for romanization with 350 copies sold at most.

Among his supporters Ben-Avi counted Vladimir Zeev Jabotinsky, Yaakov Kohen, Avigdor Hameiri, Joel Blau, Herbert Danby, and a number of prominent American Jews, such as Justice Louis Brandeis, Rabbi Abba Hillel Silver, Louis Lipsky, Meyer Weisgall, and Tamar de Sola Pool. ${ }^{58}$ Even David Yellin, a key figure in the revival of Hebrew and a noted personality in the Yishuv in his own right, had addressed to him a letter on this matter, blessing romanization to a certain extent: 'Although opposed to having the present Aramic [sic] writing entirely superseded he [David Yellin] sponsors it wholeheartedly for elementary readers and dictionaries for the special benefit of Gentiles and those Jews not conversant with the present Hebrew script. ${ }^{59}$ Ben-Avi also announced that a committee, consisting of Jabotinsky, Hameiri and himself, had been set up 'to fix a definite Latin alphabet for Hebrew, which will be based on experience already gained, as well as proposals submitted to us from all sides'. ${ }^{60}$

As for the criticisms levelled against the first romanized newspaper, there is not much evidence that survived either. The anonymous author of the article in The Jewish Chronicle of London enumerated three basic problems that caught his/her attention while reading $\mathrm{Ha}$-shavu'a ha-palestini. First, the transliteration system used by Ben-Avi seemed 'awkward and unattractive'. The purity and the beauty of the Hebrew language could not be maintained in the transliteration and this had resulted, according to the author, in the loss of the power and the significance of the Hebrew prose. The second criticism was about the difficulties that arose from the different Ashkenazi and the Sephardic pronunciations. The square alphabet kept such differences in the closet since every community vocalized the consonantal square alphabet in their own, distinct way, while preserving the same text. The decision to romanize the Hebrew script, conversely, compelled the initiators of this reform to make another decision regarding the proper pronunciation of the Hebrew 


\section{I. Aytürk}

language and the assignment of the correct vowels in the romanized text. Itamar Ben-Avi lacked the necessary training for that task, the author concluded, and was not in a position to make such decisions for all the Jews. Moreover, a disagreement on pronunciation could have led to a division between the two Jewish communities and might destroy the millennia-long textual unity of the Jews in the long run. Third, the article reflected the discomfort Ben-Avi's experiment caused in conservative circles. 'Nor are we enamoured very greatly', the author remarked 'of the Westernising impulse which is accountable for Mr. Ben Avi's experiment'. Drawing attention to the benefits of convention and tradition for national movements, the author disapproved 'the craze for obliteration of national nuances' which seemed to him 'iconoclastic in nature and somewhat confusing in practice'. ${ }^{61}$ The reaction of the Orthodox Jewish community, which was even stronger in the Yishuv than elsewhere, was also a factor to be reckoned with. Although the endeavour to romanize the Hebrew script remained an anathema for the Orthodox Jews - and that is why they intervened to stop Ben-Avi in an earlier attempt - Ben-Avi must have crossed a red line when he published a portion of the Torah in Roman characters. ${ }^{62}$ The issue of the publication of religious texts in the Roman alphabet continued to trouble Ben-Avi's relationship with the religious community and reinforced his negative image in their eyes as a proponent of religious reform. ${ }^{63}$

Itamar Ben-Avi tried to make it clear at every opportunity that it was he who came up with the idea of romanization and that he was not inspired by any other individual or by the example of another country. Observers of Ben-Avi's reform attempts, however, kindly disagreed. For example, in an article published in the Jüdische Rundschau about Ben-Avi's experimental newspaper, Dr. Fritz Löwenstein alluded to the connection between Mustafa Kemal's efforts to push through the decision of romanization of the Turkish script and the publication of Ha-shavu'a hapalestini. ${ }^{64}$ Likewise, an editorial article, published in The Jewish Chronicle of London in February 1929, indicated that 'following the example of Turkish reformers in respect to Turkish, a movement has been set on foot in Palestine for adopting Latin characters for Hebrew' ${ }^{65}$ Evidently, contemporaries of Ben-Avi's reform attempt noticed the unmistakable connection between the Turkish alphabet reform, which had taken place only a couple of months before, and the romanization of Hebrew script in Ben-Avi's publications.

Mustafa Kemal, who would be known as Atatürk after 1934, took the final decision for the adoption of the Roman alphabet in Turkey during autumn 1927, after he convinced the prime minister, İsmet (İnönü), who is said to have resisted romanization for about two years, fearing chaos in bureaucracy and at the societal level. On 23 May 1928, the Council of Ministers and the president, Mustafa Kemal, approved the creation of a Language Council in order to draw up a new Turkish alphabet based on Roman characters. A period of intense activity followed and in July 1928 the project was finalized during a meeting with the prime minister. The final report of the committee was submitted to Mustafa Kemal on 1 August 1928. He announced his approval to the public on 9 August 1928 and the Turkish Parliament passed the Law on the Adoption and Implementation of Turkish Letters on 1 November 1928 (Law No.1353). The law declared the employment of the new 
letters obligatory for all private or official purposes at the latest by June 1929, that is, within less than seven months. ${ }^{66}$ The adoption of a new Turkish alphabet was an important step in Mustafa Kemal's westernizing reform project and, like all former steps in that direction, romanization in Turkey attracted attention globally and was widely reported in the European, American, and apparently the Hebrew press.

Faced with the allegation that he was merely copying the Turkish example, BenAvi immediately sent a letter to the editor of The Jewish Chronicle explaining in detail all his efforts and endeavours for the romanization of the Hebrew script that took place years before the Turkish reform. He wrote:

These details are sufficient to prove, I believe, that any practical experiment preceeded [sic] the official attempt of Mustapha emal [sic] by four years at least. I considered these explanations necessary, not because I would not have liked to be compared to Mustapha Kemal (whom I knew personally when he was a mere capitain [sic] here in Jerusalem, and whom I greatly admire) but because 'historically' if I may use this word in the present case - it is not correct. ${ }^{67}$

On the other hand, he emphasized his influence on alphabet reforms in other countries, as in the case of Turkey, or kept a watchful eye on similar attempts in other countries such as Yugoslavia, ${ }^{68}$ Greece, ${ }^{69}$ and Egypt ${ }^{70}$ so as to consolidate his own attempt in Palestine.

Ben-Avi's favourite response to his critics in this regard was to remind them of his meeting before the First World War with Mustafa Kemal, the future leader of the Republic of Turkey, and to claim that it was he, Itamar ben-Avi, who inspired the Turkish reform in the first place. ${ }^{71}$ According to Ben-Avi, the meeting took place by sheer chance at the Hotel Kaminitz, where Mustafa Kemal, then a young Ottoman officer, was staying during his short sojourn in Jerusalem. They saw each other several times and in one of their conversations Ben-Avi suggested that the new Ottoman leadership would better adopt the Roman alphabet officially for all languages that were spoken within the boundaries of the empire. Such a drastic measure, he maintained, would create a natural 'Esperanto' for the members of various millets of the Ottoman realm, who found it difficult to communicate with each other for want of a common medium in print. Their conversation continued late into the night and they parted from each other with a toast in French: 'Aux lettres latines pour l'hébreu!"72

In spite of Itamar Ben-Avi's arguments to the contrary, the chronological sequence of the Turkish reform and Ben-Avi's attempt in Palestine makes one wonder whether there could have been a spillover effect in this case. It is true that Ben-Avi had been a devotee of the cause of romanization long before the Turkish reform project was launched and he did publish a book in the Roman type in 1927. But, chronologically speaking, the date of the publication of Ha-shavu'a ha-palestini follows the Turkish romanization so seamlessly that it is fair to suspect a connection between the two events. One can reasonably argue that success in Turkey must have encouraged Itamar Ben-Avi to bring his lifelong dream of publishing a Hebrew newspaper in Roman type to fruition.

The third and final attempt of Itamar Ben-Avi to introduce the Latin alphabet into the Hebrew language came in late 1933. This time, having taken into account his 
former failure, Ben-Avi decided to publish an independent weekly with his own money. ${ }^{73}$ The first issue of the new weekly, Deror (Liberty), appeared on 17 November $1933 .{ }^{74}$ It proved to be a great success in the first week, especially among the new immigrants from Hitler's Germany, most of whom found it difficult to acclimatize in the hebraicized culture of the Yishuv ${ }^{75}$ The 6,000 copies sold in the first week was indeed a great number by the standards of the Yishuv. However, the number declined to 2,000 in the second week and remained around 1,400 afterwards. ${ }^{76}$ Ben-Avi was proud to receive 1,200 applications for subscription from all over the Jewish world: Salonica, Teheran, Cairo, Lwow and New York. There were 500 subscribers in the Yishuv, more than 200 in Egypt and around 150 in Europe, Asia and America. ${ }^{77}$

In an important article that appeared in the first issue, Itamar Ben-Avi stated his aims in publishing Deror. First of all, he wanted to return to the Hebrew nation what belongs to it as an inheritance from its ancient fathers, the alphabet that was revealed to Moses, from which all other alphabets were derived. 'The language of Canaan will', thereby, 'be the property of all Israel', he believed and it would again rule the Mediterranean as it did in its days of glory. ${ }^{78}$ Second, he emphasized the practical benefits of the shift to the Roman alphabet in that tens of millions could easily read and write Hebrew and not stumble as when they encounter the square letters. This reform, he opined, was necessary for non-Jews, too, as 'we want millions of Hebrew speakers: Arabs, Englishmen, French, Russians, Japanese, and not only the Jews'. ${ }^{79}$

In addition to the former supporters of Avi and Ha-shavu'a ha-palestini, some new important figures either contributed articles to Deror, or encouraged Ben-Avi in this adventure. Among those were Arthur Koestler, Joseph Nedava, Nahum Slouszch, Gershon Agronsky, J.L. Magnes, Meir Dizengoff and Eleazar Rokeah. Owing to Ben-Avi's unbridled admiration for and backing of Mussolini, ${ }^{80}$ there were rumours in the Yishuv that Deror was covertly financed by the Italian government. There is, however, no evidence to corroborate that allegation. ${ }^{81}$ Yaakov Cohen, the poet, who was formerly a defender of romanization, changed his mind in the meantime and remained an opponent afterwards. Saul Tschernichowsky stood firmly against the idea as well, and H.N. Bialik kept silent as always. With the exception of V.Z. Jabotinsky, Zionist factions remained aloof, if not hostile, as a result of Ben-Avi's cantonization plan which he continued to propagate in his new newspaper. It is difficult to estimate the popular reaction in the Yishuv, but it is telling that he was attacked near the Grand Synagogue on the Allenby Street in Tel Aviv and beaten up by the opponents of romanization. ${ }^{82}$

Yet the greatest obstacle that Itamar Ben-Avi had to overcome continued to be the opposition of the orthodox religious establishment in the Yishuv. A confrontation became inevitable when Ben-Avi started to publish, as he had also done in $\mathrm{Ha}$ shavi'a ha-palestini, portions of the Torah in Roman script. Romanization of whole chapters from the Bible, that appeared under the title Sipurei ha-mikra' (Tales of the Bible), antagonized the rabbis, for whom this was nothing less than sacrilege. One of them, Rabbi Shmuel Barukh Shulman, sent a letter to Itamar Ben-Avi, on behalf of Rabbi Avraham Yitzhak Ha-Kohen Kook, ${ }^{83}$ the Chief Ashkenazi Rabbi of Palestine, requesting that those transliterations be discontinued. 'I cannot restrain myself from announcing to you', Rabbi Shulman wrote, '[that] it will cause a great trouble to anyone with a bit of Jewishness in him to see parts of the Torah and whole 
chapters, printed on a paper, which is eventually thrown away'. ${ }^{84}$ Apart from that, Rabbi Shulman underlined the importance of the square alphabet, which, he said, was consecrated for the holy texts. Therefore, the transliteration of those texts into other alphabets constituted, in their eyes, a disrespectful attitude toward Judaism. Ben-Avi published Rabbi Shulman's letter in Deror together with a short note, where he explained his practical objective in the transliteration of the Hebrew Bible, and added that he would respect the judgement of the rabbis and discontinue publication of transliterated chapters from the Bible. ${ }^{85}$

Approximately one month later Ben-Avi received yet another letter from Rabbi Shulman, again on behalf of Rabbi Kook, this time stating a rabbinical opinion declaring the position of the rabbinate on the issue of alphabet:

My teacher, my rabbi, our master ... Rabbi Kook ... the chief rabbi of our holy land told me in connection with your distinguished newspaper, Deror, that it was his desire that all secular words in literature [kol divrei he-hol she-be-safrut $]$. . the newspapers, and especially the dailies, that are usually rolling over dung heaps and all undignified places - be written not with the holy letters of the Assyrian alphabet [square letters], which is consecrated for the basic holy books of the Torah, the Tanakh. ${ }^{86}$

A close reading of the letter reveals a slightly confusing text that is silent on the applicability of the Roman alphabet to the Hebrew language, yet opposed to the publication of secular works in the square letters. Be that as it may, Itamar Ben-Avi celebrated the rabbinical opinion as a 'great victory for the Latin letters in our language ${ }^{87}$ and interpreted it as acquiescence to the publication of romanized secular newspapers in Hebrew.

After the appearance of No.15-16 of Deror on 25 March 1934, Itamar Ben-Avi decided to discontinue the paper. It is striking to read the passages in his memoirs where he enumerated the reasons that forced him to make that decision. He basically put the blame on orthographic problems and erroneous editorial policies he undertook during those four months. He believed that the lack of necessary typeface, which was not available in Jerusalem publication houses, caused difficulties for the readers. He also assumed that a different editorial policy might have increased the appeal of the weekly in the eyes of the local readers. Among his many regrets were the extreme length of some of the articles, which discouraged beginners; the small number of local news and advertisements; the lack of entertaining, 'light' columns; smallness of the print characters and the unavailability of a Hebrew dictionary in Roman characters. ${ }^{88}$ It did not occur to Ben-Avi, or more probably he did not want to admit that the failure of this project was due less to those causes than to an intense animosity toward the very idea itself. Romanized Hebrew looked like a fantasy or a temporary measure to accommodate the new immigrants in the Mandate at best; at worst, it was perceived as an abuse of a national asset, abused by the son of the celebrated Eliezer Ben-Yehuda, to make things worse.

Vladimir Zeev Jabotinsky (1880-1940) was one of the most important figures in Jewish politics in the first half of the twentieth century. ${ }^{89}$ After a brief literary and 
journalistic career in his hometown, Odessa, he fully immersed himself in the Zionist politics of the day. He was the founder of the Jewish Legion, which fought alongside the Allied forces in the First World War, and later emerged as the most important critic of the British policies in Mandatory Palestine and of those Zionists who, Jabotinsky argued, went too far in accommodating the British. His clash with the mainstream Zionist leadership reached its peak after the assassination of Chaim Arlosoroff, a leader of the Labour Zionists, in 1933 and resulted in his resignation from the Zionist Organization. Being the founder of the New Zionist Organization in 1935, Jabotinsky was in the centre of that schism which was to play a decisive role in Israeli politics until today. He founded the youth movement, Betar, which adopted his political ideology and spread it in the Jewish world. The Herut Party in Israel incorporated the Betar ideals and the heritage of Jabotinsky. ${ }^{90}$

In early 1927, V.Z. Jabotinsky received a gift copy of Itamar Ben-Avi's newly published book, Avi, and wrote him from Paris, where he lived for some time, to congratulate Ben-Avi for his latest accomplishment:

You have done an important deed, sir, with this step of yours, a deed that will be remembered and that will have an impact. I do not say this as a compliment, nor as an exaggeration.... And perhaps they [conservatives and purists] used to comfort each other with the usual excuses - 'What can we do,' 'Endless trouble,' 'It is impossible otherwise'... The last excuse is more dangerous than all, because reason and evidence cannot help against the 'impossible': There is only one thing that works against it - the example, the fact, the deed. To show everyone, without explanation or apology, that indeed it is 'possible' - and here is the book. So did Ben-Yehuda do in his time: Instead of discussing the 'possibility' of a Hebrew family, he set about to create that family. You have, truly, followed in the footsteps of that great man with your deed. ${ }^{91}$

An open declaration of support for the romanization of Hebrew does indeed seem at first sight to be one of the last things that can be expected from this great Jewish nationalist, who was even called a fascist by his critics. In the light of Jabotinsky's lifelong commitment to western values and his animosity toward all things oriental, however, the letter to Ben-Avi comes as less of a surprise. ${ }^{92}$

It is likely that Jabotinsky's espousal of the romanization of Hebrew was a consequence of his own experience as an adult, trying to learn the language. In the same letter to Itamar Ben-Avi, he disclosed that he had been using 'Latin letters in [his] private notes for about twenty years' ${ }^{93}$ In the years 1907 and 1908, when he restarted his study of the Hebrew language, Jabotinsky 'copied entire chapters (in Latin characters) from Hebrew books, to improve his vocabulary'. ${ }^{94}$ The difficulties he encountered during his study of Hebrew proved to be his main ammunition in his future case for the romanization: adults, after all, do not prefer to study a language under the supervision of a teacher; they learn languages by self-teaching methods, he maintained. The self-study method does not lend itself fully to the Hebrew, however, because of the spelling and pronunciation problems that are inherent in the square alphabet:

The script is the principal obstacle before the spread of the Hebrew language. In Eretz Israel itself there are thousands of people already, who can speak 
[Hebrew], but who dare not read a newspaper... An adult, who wants to study French or German, studies 500-600 words, some grammar and starts reading; but in Hebrew this is not enough at all. For instance: The word 'מדבר' can be read in various ways: Midbar, mi-davar, medaber, ... ${ }^{95}$

Jabotinsky felt so passionately about the prospect of an alphabet reform, that he, the theorist of hadar, could not contain his anger when the topic was the square alphabet: 'A writing system, for which there is no proofreader to be found unless one is a professor of Semitic languages, is no system at all: it is absurd. A beautiful absurdity, a holy one, whatever you like - but absurd. ${ }^{96}$ These sentences exemplify Jabotinsky's functionalist approach to the problem of alphabet. Feeling no emotional attachment to the traditional Jewish alphabet, he was ready to sacrifice it for the comfort of the thousands of adult students whom he expected to learn Hebrew soon: 'I do not touch [harm] the sanctity of the square letters, even though I cannot protect them either. And I would not have mourned if I had woken up one morning, and, lo and behold, the Latin alphabet had replaced the square script. ${ }^{97}$ He continued to enumerate two solutions to the problem at hand: either the Jews would invent a new system of writing, that is, a new alphabet; or they would have to adopt the Latin alphabet. He added that he preferred the latter solution. ${ }^{98} \mathrm{~A}$ few months before his death in 1940 he told a group of Hebrew teachers in New York that 'the Hebrew script is foreign to him, [and] to the Jewish child in America... The Hebrew script has indeed become holy to us and is liked by us, but so was the Turkish script [sic] to the Turks, it was a difficult operation but [proved to be] necessary and beneficial'. ${ }^{99}$ Jabotinsky also worked on a teaching manual for the students of Hebrew throughout the 1930s, which employed romanized Hebrew for the benefit of the new beginners. ${ }^{100}$ Moreover, he corresponded with his only son, Eri, writing letters in romanized Hebrew till the end of his life. This personal conviction, however, did not translate into political action and he did not try to impose his views on other Revisionist Zionists.

Itamar Ben-Avi's several attempts to disseminate his views regarding the romanization of the Hebrew alphabet remained isolated and eventually failed, as did Jabotinsky's personal example. Their failure might be attributed basically to two reasons. First, we have to take into account the relationship between the political elite and the religious establishment in this case. The romanization project met with the opposition of the religious establishment, Zionist or non-Zionist, in the Yishuv. In their being westernizers, Ben-Avi and Jabotinsky were seen by the rabbis as threats to the religious as well as national traditions of the Jewish people, as the square alphabet had been employed as the medium of those traditions since the Second Temple Period. The rabbinic hostility toward the romanization of the Hebrew alphabet was strong enough to break the romanizing current at its early stages. The fact that consensus and compromise characterized the relations between secular Zionists and the rabbinical establishment further contributed to the success of their opposition. Zionist orthodox rabbis were able to banish questions that related to cultural matters, including romanization, from the agendas of various Zionist organizations. They were the ultimate arbiters on the Hebrew alphabet and 
they crushed the nascent romanization movement at its birth with the tacit approval of secular Zionists.

Second, Ben-Avi and Jabotinsky failed to garner support even among the secular Zionists. What eventually determined the success or failure of romanization among this group was the secular definition of national history and its role in national identity. Zionist ideology was based on a rejection of the diasporic existence of the Jews and aimed at recreating a Hebrew-speaking community and government on the ancient land of the Jews. In this respect, Zionists considered themselves as heirs to a great religio-literary tradition. The texts, religious or otherwise, that dated back to that ancient community and the square alphabet in which those texts were written enjoyed great prestige among the Jews, not the least among the members of the secular stratum, and were certainly accepted as part of the national history and identity. Moreover, the square letters did not have a negative connotation that evoked unwanted images even in the minds of the secular Jews. After all, the glorious Jewish past was written using those letters; thus, it was that heritage that the Zionists wanted to restore and put into use for modern politics, securing the legitimacy of the future Jewish state.

\section{Notes}

I would like to thank Professors Avigdor Levy and Jacob M. Landau for their help and suggestions on earlier versions of this article. This study has been funded by the Department of Near Eastern and Judaic Studies at Brandeis University and a Research Development Grant from Bilkent University.

1. A. Koestler, Promise and Fulfilment: Palestine, 1917-1949 (London: Macmillan \& Co. Ltd., 1949), p. 314 .

2. Ibid., pp.314-15.

3. J. Goody, The Interface between the Written and the Oral (Cambridge: Cambridge University Press, 1991), pp.53-4.

4. A.J. Toynbee, Survey of International Affairs: 1928 (London: Humphrey Milford for Oxford University Press, 1929), pp.216-19. Romanians were the only exception to that rule.

5. F. Coulmas, The Writing Systems of the World (Oxford: Basil Blackwell, 1990), p.241.

6. Of course, reference is being made here to those cases where an already literate society abandons its writing system and adopts a new one. Adoption of a writing system by a hitherto oral culture, on the other hand, is a completely different and much more common phenomenon.

7. See the collection of articles in J.A. Fishman (ed.), Advances in the Creation and Revision of Writing Systems (The Hague: Mouton, 1977); and S. Shraybom Shivtiel, 'The Question of Romanization of the Script and the Emergence of Nationalism in the Middle East', Mediterranean Language Review, Vol.10 (1998), pp.179-95; V. Alleton, 'La transcription alphabétique du chinois: forme et pédagogie du pinyin en République Populaire de Chine', Cahiers de linguistique d'orientalisme et de slavistique, Vol.10 (1978), pp.9-21; N. Gottlieb, 'Language and Politics: The Reversal of Postwar Script Reform Policy in Japan', Journal of Asian Studies, Vol.53 (1994), pp.1175-98. The consequences of the introduction of moveable type and book publishing on the long-term stability of writing systems and orthography in the Near East are covered in detail in E. Hanebutt-Benz et al., Sprachen des Nahen Orients und die Druckrevolution (Westhofen: Verlag Skulima, 2002).

8. 'Alphabet, Hebrew', The Encyclopaedia Judaica (Jerusalem: Keter Publishing House); A. Yardeni, The Book of Hebrew Script: History, Palaeography, Script Styles, Calligraphy and Design (Jerusalem: Carta, 1997); R. Gonen, Toldot ha-ketav ha-'ivri (Jerusalem: Misrad ha-hinukh ve-ha-tarbut, 1970); D. Diringer, The Story of the Aleph Bet (New York and London: Thomas Yoseloff, 1960).

9. Sanh. 21b.

10. Ber. 55a.

11. Pes. $87 \mathrm{~b}$.

12. Av. Zar. 18a. 
13. Sanh. 102b.

14. L. Ginzberg, The Legends of the Jews: From the Creation to Jacob (trans. H. Szold) (Baltimore, MD and London: The Johns Hopkins University Press, 1998), pp.5-6.

15. 'Alphabet, Hebrew, in Midrash, Talmud, and Kabbalah', The Encyclopaedia Judaica; and J. Drucker, The Alphabetic Labyrinth: The Letters in History and Imagination (London: Thames and Hudson, 1995), pp.129-58.

16. See W. Weinberg, Tikun ha-ketav ha-'ivri (Jerusalem: The Magnes Press, 1972); W. Weinberg, Essays on Hebrew (ed. P. Citrin) (Atlanta, GA: Scholars Press, 1993); M. Landmann, Reform of the Hebrew Alphabet (trans. David J. Parent) (n.p.: Applied Literature Press, 1976).

17. The earliest supporter of the Latin characters for the Hebrew language in the Diaspora was Isaak Rosenberg. Rosenberg, professor of modern and Semitic languages, taught probably at a university in the Austro-Hungarian Empire and was the former director of the Lämel Boys' School in Jerusalem. Rosenberg wrote a handbook for the study of the Hebrew language in 1898, in which he declared his support for the introduction of Latin characters in secular works and especially in correspondence: 'Ich halte nämlich die Zeit für gekommen, neben den üblichen Schriftarten, für profane Druckwerke und besonders für die Correspondenz im Hebräischen die Lateinschrift zu adaptieren, und wollte den Nachweis erbringen, daß die hebräische Sprache mit den üblichen Schriftarten nicht unauflöslich verwachsen ist.' See J. Rosenberg, Hebräische ConversationsGrammatik: Kurzgefasstes theoretisch-praktisches Lehrbuch der modernen hebräischen Conversationsund Schriftsprache (Vienna, Budapest and Leipzig: A. Hartleben's Verlag, 1898), p.9. He also provided a Hebrew text transcribed into Latin characters on pages 58 to 61 .

18. His parents first called him Ben Zion and he later on changed his name into Itamar. For a short introduction, see 'Ben-Avi, Ithamar', The Encyclopaedia Judaica. The best and most detailed source of information is Ben-Avi's autobiography; see I. Ben-Avi, 'Im shahar 'atzma'utenu: Zikhronot-hayav shel ha-yeled ha-'ivri ha-ri'shon (Tel Aviv: Ha-va'ad ha-tziburi le-hotza'at kitvei Itamar Ben-Avi, 1961). Also see H. Ben-Yehuda, Nose' ha-degel: Hayei Itamar Ben-Avi (Jerusalem-Talpiot: Ben Yehudah - Hotza'ah la-'or le-zekher Eliezer Ben Yehuda, [1944]); City Council of Netanyah, Itamar Ben-Avi: Kovetz zikaron le-yom shuvo 'el 'admato (Tel Aviv: M. Shaham Publication House, 1947); D. Omer, 'Ahavat Itamar (Tel Aviv: Am Oved, 2001).

19. On the concept of the 'New Jew', see G.L. Mosse, Confronting the Nation: Jewish and Western Nationalism (Hanover and London: Brandeis University Press, 1993), pp.161-75; S. Almog, Zionism and History: The Rise of a New Jewish Consciousness (Jerusalem: The Magnes Press, 1987), pp.84-176; D. Biale, Power and Powerlessness in Jewish History (New York: Schocken Books, 1987), pp.118-44.

20. Interview with Ms. Rina Raz, the only surviving daughter of Itamar Ben-Avi (Jerusalem, 25 April 2002).

21. [I. Ben-Avi], 'Ri'shonot', Deror, No.2, 24 Nov. 1933, p.2.

22. J. Nedava, 'Projects for the Latinization of the Hebrew Script', Hebrew Studies, Vol.26 (1985), p.138.

23. I. Ben-Avi, Avi (Yeruçalaym: Hassolel, 5689-1927-X Le-hatzharat Balfur), p.IX. (The original transliteration by Itamar Ben-Avi.)

24. Hemda Ben-Yehuda's typewritten notes in English, entitled, 'Ben-Yehuda: His Life and Work', Chapter 49. Central Zionist Archives, Jerusalem, A43/103.

25. [Ben-Avi], 'Ri'shonot', p.2; Nedava, 'Projects for the Latinization', p.138.

26. Ben-Avi, 'Im shahar 'atzma'utenu, pp.184-5.

27. Ibid., pp.187-8.

28. Nedava, 'Projects for the Latinization', p.138.

29. [Ben-Avi], 'Ri'shonot', p.2.

30. Ibid. Nedava mentions 'a hostile letter from a Jerusalem rabbi' as the reason for failure. Nedava, 'Projects for the Latinization', p.138.

31. I. Ben-Avi's letter to the editor of The Jewish Chronicle of London on 7 March 1929. The letter was not published in The Jewish Chronicle, but a copy of it can be found in The Palestine Weekly, 5 April 1929, pp.364-5.

32. [Ben-Avi], 'Ri'shonot', p.2.

33. On the Canaanite movement in 1940s and in the State of Israel, see J.S. Diamond, Homeland or Holy Land? The 'Canaanite' Critique of Israel (Bloomington: Indiana University Press, 1986); and Y. Shavit, The New Hebrew Nation (London: Frank Cass, 1987).

34. For the most extensive presentation of his views on the Canaanite movement, see I. Ben-Avi, Kena'an 'artzenu: 5000 shenot yisra'el 'al 'admato, le-lo' hafsakah (Tziyon [Jerusalem]: n.p., 1932). 


\section{I. Aytürk}

35. Ibid., p.104.

36. Ibid.

37. The epitaph read: 'Le-mehayeh leshonenu Eliezer Ben-Yehuda.' A photograph of the inscription and the grave can be seen in H. Ben-Yehuda, Ben Yehuda: Hayav u-mif'alo (Ben Yehuda hotza'ah la-'or, Jerusalem, 1940), p.332.

38. Ben-Avi, Avi. Avi is a very rare book and a collectors' item. There is said to be a first edition, which was distributed to family members and friends, but I have not seen a copy of that edition so far. All copies extant in libraries are marked as the second edition.

39. Nedava, 'Projects for the Latinization', p.139.

40. [Ben-Avi], 'Ri'shonot', p.2.

41. Nedava, 'Projects for the Latinization', p.139.

42. There were only 20 issues of the weekly supplement in two volumes. The sixteenth and the seventeenth issues in the first volume and the second and third issues in the second volume were published together. A complete set can be consulted at the Jewish National and University Library in Jerusalem. The title of the supplement had undergone an evolution as Itamar Ben-Avi adjusted his transliteration system. The first issue is titled ha Şavu'a ha Palestini, the fifth to seventh ha Şavuja ha Palestini (Ben Avi used the Latin character 'j' in place of the Hebrew letter "y" in his first transliteration system), the eighth to eleventh ha Shavuaj ha Palestini, the twelfth and thirteenth ha Shavuaa ha Palestini, and the rest ha Shavua ha Palestini. The first issue appeared on 13 Dec. 1928 and the last in May 1929. Ben Avi mentions elsewhere the Arab riots in Palestine in August 1929 that resulted in many Jewish casualties, and particularly the massacre in Hebron, as the cause for the suspension of the supplement. Ben Avi might have feared for his life after his attempt to publish an Arabic page in roman characters and in the tense environment during and after the riots the Zionist establishment might have advised him to discontinue publication. However, this explanation does not account for the missing issues between April and August 1929.

43. [I. Ben-Avi], 'L qor'einu wl qor'oteynu', ha Şavu'a ha Palestini, Vol.1, No.2, 8 Teveth 5689 (21 Dec.1928), p.1. All references to the articles published in the supplement follow Ben-Avi's own transliteration system.

44. [I. Ben-Avi], 'Sefatenu - Esperanto ha Yahadut ha Jolamit: Raq ha Otiyot ha Latiniyot te'afsherna Hhalom yafeh zeh', ha Şavuja ha Palestini, Vol.1, No.5, 29 Teveth 5689 (11 Jan.1929), p.1.

45. A. Cust, 'Cantonisation: A Plan for Palestine', Journal of the Royal Central Asian Society, Vol.23 (1936), pp.194-220. This plan was eventually rejected by the Peel Commission as unworkable. See Palestine Royal Commission Report: Presented by the Secretary of State for the Colonies to Parliament by Command of His Majesty, July 1937 (London: His Majesty's Stationery Office, 1937), pp.377-9.

46. I. Ben-Avi, Palestinism: Moulding a Common Country for Two Brother Peoples (Jerusalem: Hassolel, 2nd enlarged edn, 1929).

47. 'Rien ne contribuera mieux à hater et à completer le processus de "palestinisation" de tous les citoyens de notre pays que la latinisation des alphabets hébraïque et arabique.' I. Ben-Avi, L'enclave (Paris: Les Éditions Rieder, 1931), p.93.

48. 'Our Hebrew Page', The Palestine Weekly, 14 Dec. 1928, p.550. Ben-Avi did not take into consideration the essential difference between the Turkish and Arabic languages in that they belong to two different language families.

49. 'Our Supplement in Latin Characters', The Palestine Weekly, 12 April 1929, p.371; 'Mador la aaravit', Ha Shavua Ha Palestini, Vol.2, No.1, 2 Nissan 5689 (12 April 1929), p.6.

50. 'Qismna el aarabi', Ha Shavua Ha Palestini, Vol.2, No.1, 2 Nissan 5689 (12 April 1929), p.7.

51. 'Arabic in Latin Characters', The Palestine Weekly, 10 May 1929, p.441; Ben-Avi, L'enclave, p.94.

52. 'Arabic in Latin Characters', pp.441-2.

53. 'Ben-Avi, Ithamar', The Encyclopaedia Judaica.

54. 'Sefatenu - Esperanto ha yahadut ha jolamit', p.1.

55. Ibid.; 'Li-qrat ha nittzahon (li shnatenu ha sheniya)', Ha Shavua Ha Palestini, Vol.2, No.1, 2 Nissan 5689 (12 April 1929), p.2.

56. 'Ta'aarukha b New York 1 iivrit b otiyot latiniyot', Ha Shavuaj ha Palestini, Vol.1, No.11, 12 AdarRishon 5689 (22 Feb.1929), p.3; 'Iittoneynu be Sifriyat New York', ha Shavua ha Palestini, Vol.1, No.16-17, 24 Adar-Bet 5689 (5 April 1929), p.7. 
57. 'Shanah shelishit 1 nissayon nojaz: Qidma mudraga gam me-eyn Mustafa Kemal', ha Şavuja ha Palestini, Vol.1, No.7, 14 Shevat 5689 (25 Jan.1929), pp.1-2; Y. Tagger, 'Le taqqanat ha ketiv ha ivri be otiyot latiniyot: Mikhtav la oorekh', Ha Shavua Ha Palestini, Vol.2, No.2-3, 13 Nissan 5689 (23 April 1929), p.3.

58. 'Raq hathhalah', ha Şavuja ha Palestini, Vol.1, No.3, 15 Teveth 5689 (28 Dec.1928), p.1. The wellknown French orientalist Louis Massignon was also among his supporters.

59. Itamar Ben-Avi's letter to the editor of The Jewish Chronicle, 7 March 1929, published in The Palestine Weekly, 5 April 1929, pp.364-5.

60. Ibid. More information about the committee and its meetings can be found in 'Wa'aad ha ketiv: Yeshiva meyuhhada bi-Yrushalayim li-qriaat ha ketiv b otiyot latiniyot', ha Shavuaj ha Palestini, Vol.1, No.11, 12 Adar-Rishon 5689 (22 Feb.1929), p.2; 'Ha yeshiva ha rishona le waad ha ketiv be veyt ha adon Zaltzman', ha Shavuaa ha Palestini, Vol.1, No.13, 26 Adar-Rishon 5689 (8 March 1929), p.2.

61. 'Press Extracts: Hebrew Transliteration Again - From the "Jewish Chronicle"', The Palestine Weekly, 5 April 1929, p.364. Italics original.

62. 'Be Reshit Bara' Elohim', ha Shavua ha Palestini, Vol.1, No.14, 3 Adar-Bet 5689 (15 March 1929), p.2.

63. Itamar Ben-Avi's proposals for religious reform can be found in his Kera'on (Jerusalem: Hassolel, 1935). Three years later he published a supplement to the Kera'on, including portions of the Torah in the Latin alphabet. See I. Ben-Avi, Yeshâyaùt (Isaïanism): Toséphet La "Qëraon” Îmm Pirqë Tanak' b Otiyot Latiniyot (Natanyah-Haçi shëbvet Menashé: n.p., 5699/1938).

64. Dr. F. Löwenstein, 'For the Benefit [sic] of our [sic] Gentile Readers', Jüdische Rundschau, No.102, 28 Dec. 1928, p.723.

65. Editor, 'Transliterating Hebrew', The Jewish Chronicle, 1 Feb. 1929/5689, pp.5-6; also see 'Press Extracts: Hebrew Transliteration Again', p.364.

66. For more information on the Turkish alphabet reform, see B. Şimşir, Türk Yazı Devrimi (Ankara: Türk Tarih Kurumu Basımevi, 1992); H. Yorulmaz (ed.), Tanzimat'tan Cumhuriyet'e Alfabe Tartışmaları (Istanbul: Kitabevi, 1995); and Toynbee, Survey of International Affairs: 1928, pp.215-34.

67. Itamar Ben-Avi's letter to the editor of The Jewish Chronicle, 7 March 1929, and The Palestine Weekly, 5 April 1929, pp.364-5. Also see [I. Ben-Avi], 'Turkey's Place in the Near East: Kemal's Ascent to Glory', The Palestine Weekly, 8 Feb. 1929, p.181.

68. 'Otiyot Latiniyot Le Yugoslavia', ha Shavua ha Palestini, Vol.1, No.16-17, 24 Adar-Bet 5689 (5 April 1929), p.7.

69. 'Gam Ha Yewanim Roxim Otiyot Latiniyot', ha Shavuaj ha Palestini, Vol.1, No.8, 20 Shevat 5689 (31 Jan.1929), p.3.

70. 'Melekh Mixraym Nocteh La Latinit? Haxxajato ha ahharona raq xajad rishon jal Derekh zot', $h a$ Shavuaj ha Palestini, Vol.1, No.8, 20 Shevat 5689) (31 Jan.1929) p.3.

71. Ben-Avi recounted the details of his several, very interesting meetings with Atatürk in a separate chapter in his autobiography. See I. Ben-Avi, 'Pegishati 'im Mustafa Kemal, nesi' turkiyah le-'atid', in 'Im shahar 'atzma'utenu, pp.213-18. If the meeting did indeed take place, it must have been in 1911, when Mustafa Kemal was trying to reach the Ottoman Tripoli to fight the Italian invasion of the same year. The sea route to Tripoli was blocked by the Italian navy and thus he had to travel first to Palestine and then to Tripoli through British-dominated Egypt. Specialists on this period of Turkish history, however, doubt if such a meeting ever took place. There is no other source that confirms Ben-Avi's own account, though Kemal Atatürk's life is documented thoroughly. I am of the opinion that they met in Jerusalem, but, given Ben-Avi's reputation for inflating his self-importance through such meetings and acquaintances, I do not necessarily trust all the details in his memoirs regarding this meeting.

72. Ibid., p.218.

73. Itamar Ben-Avi had never been a rich man. He spent the compensation he received when he resigned from Do'ar ha-yom on the new weekly, despite the opposition of his wife, who complained about his 'tendency to spend their last prutah'. See Ben-Avi, 'Im shahar 'atzma'utenu, pp.513-14.

74. See G. Tzafroni, “'Deror” - 'iton ‘ivri ha-mudpas mi-semo’l le-yamin', Kesher, Vol.1 (1987), pp.6572. There were altogether 16 issues of Deror, and the last issue, No.15-16, was published on 25 March 1934. A complete set can be consulted at the Jewish National and University Library in Jerusalem.

75. Ben-Avi, 'Im shahar 'atzma'utenu, p.514. 


\section{I. Aytürk}

76. Ibid. Tzafroni claimed that the actual number of sales after the second week was down to 800 . Tzafroni, "Deror", p.71. Although this article contains much valuable information, there are no references in the text which can be cross-checked.

77. 'Ha shavuôn moné kevar 1200 menuyim we qonim temidiyim', Deror, No.4, 8 Dec. 1933, p.2. (Itamar Ben-Avi's own system of transliteration is followed, when quoting from romanized pages of Deror.) One has to remember, however, that Ben-Avi was somewhat inclined to inflate these numbers.

78. I. Ben-Avi, 'Ma ánu rotzim?', Deror, No.1, 17 Nov. 1933, pp.1-2.

79. Ibid.

80. 'Mah she-nahutz lanu ba-rega' zeh hu' - Mussolini 'ivri', Deror, No.2, 24 Nov. 1933, p.ふ. This article was published in the page where Hebrew was written with the square alphabet. Deror always included one such page for the benefit of the readers.

81. Tzafroni, "“Deror", p.70.

82. Ibid., p.66.

83. Rabbi Kook was and remains one of the most influential religious thinkers on the issue of Jewish nationhood, one who tried to redefine the ties between the Jew and 'Eretz Yisra'el and link the return of the Jews to their ancestral land to messianic redemption. See S. Avineri, The Making of Modern Zionism: The Intellectual Origins of the Jewish State (New York: Basic Books, 1981), pp.187-97; G. Shimoni, The Zionist Ideology (Hanover, NH and London: Brandeis University Press, 1995), pp.145-51.

84. 'Ha-vikuhim mi-saviv la-'otiyot ha-latiniyot: Da'at ha-rav S. B. Shulman mi-rushalayim', Deror, No.10, 19 Jan. 1934, p.ふ.

85. I. Ben-Avi, “Al pi bakashat ha-rav ha'i ga'on Ha-Kohen Kook', Deror, No.10, 19 Jan. 1934, p.ふ.

86. 'Nitzahon gadol la-'otiyot latiniyot be-sefatenu', Deror, No.14, 16 Feb. 1934, p.ঙ.

87. Ibid.

88. Ben-Avi, 'Im shahar 'atzma'utenu, pp.515-18. Itamar Ben-Avi's plans to prepare a Hebrew dictionary to be published entirely in the Latin alphabet by the German publication house Langenscheidt Verlag was mentioned earlier. I contacted Langenscheidt Verlag and inquired about their correspondence with Itamar Ben-Avi; however, I was informed that their records from the 1930s had been discarded. Letter from Langenscheidt Verlag to the author, 18 Dec. 2002.

89. The literature on Jabotinsky abounds and is growing. Jabotinsky's autobiography contains much information especially about his early years. See Z. Jabotinsky, 'Sipur yamai', in Ketavim: Avtobiyografiyah (Jerusalem: Eri Jabotinsky, 1947), pp.9-189. Two important and sympathetic biographies are J. B. Schechtman, Rebel and Statesman: The Life and Times of Vladimir Jabotinsky (foreword by M. Begin) (Silver Spring: Eshel Books, n.d.); S. Katz, Lone Wolf: A Biography of Vladimir Jabotinsky (New York: Barricade Books, 1996), 2 vols. An account of Jabotinsky's slow drift toward Zionism and Revisionism can be found in M. Stanislawski, Zionism and the Fin de Siècle: Cosmopolitanism and Nationalism from Nordau to Jabotinsky (Berkeley: University of California Press, 2001), pp.116-237.

90. The Likud Party in Israel is actually an electoral bloc dominated by the Herut. Y. Shapiro, The Road to Power: Herut Party in Israel (trans. R. Mandel) (Albany: State University of New York Press, 1991); and C. Shindler, The Land Beyond Promise: Israel, Likud and the Zionist Dream (London and New York: I.B. Tauris, 2002).

91. V.Z. Jabotinsky, Paris, to I. Ben-Avi, Tel Aviv, 30 March 1927, The Jabotinsky Archive, Metzudat Zeev, Tel Aviv, No.2/17 - 1 .

92. Michael Stanislawski underlines Jabotinsky's cosmopolitan background, his immersion in Russian culture as an adolescent, his apathy toward Judaism and contrasts him with other Eastern European Jewish leaders, who were generally born into observant families in shtetls, received a heder education and then converted to nationalism after being exposed to the haskalah literature.

93. V.Z. Jabotinsky to I. Ben-Avi, 30 March 1927. The Jabotinsky Archive, Metzudat Zeev, Tel Aviv. No.2/17 - 1 .

94. Schechtman, Rebel and Statesman, p.170.

95. Quoted in S. Haramati, 'Ha-lashon ha-'ivrit ba-mishnato shel Zeev Jabotinsky', Leshonenu la- 'am, Vol.32, No.3-5 (1981), p.132.

96. Z. Jabotinsky, 'Otiyot', Do'ar ha-yom, 5 April 1929.

97. The article, 'Stinografiyah', appeared in Ha-'aretz in 1926; quoted in Haramati, 'Ha-lashon ha-'ivrit', p.133. 
98. Ibid.

99. Ibid., p.140.

100. Z.V. Jabotinsky, Tarya'g milim. Autograph manuscript, The Jabotinsky Archive, Metzudat Zeev, Tel Aviv. No.\$1/12/6/1. It was published posthumously first in South Africa, and then in Jerusalem by his son Eri Jabotinsky. The title of the book, Tarya"' $g$ milim (613 Words), is an excellent example of the appropriation and secularization of religious symbols by the Jewish nationalists. There are 613 commandments or good deeds, mitzvot, in the Torah that every Jew is enjoined to observe. Jabotinsky, on the other hand, taught 613 necessary words to initiate his students into Hebrew. 